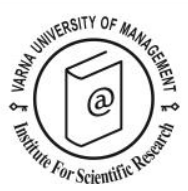

\title{
An assessment of brand Zimbabwe's competitiveness and attractiveness as a tourism destination
}

\author{
Erisher Woyo ${ }^{1}$
}

Received: 19/03/2018

\begin{abstract}
1 International University of Management. Address: 21-31 Hercules St, Dorado Ext 1, Windhoek, Namibia Private Bag, 14005, Bachbrecht, Windhoek. Phone: +264812458161, E-mail: elishawoyo77@gmail.com
\end{abstract}

Supervisors: Professor, Dr. Elmarie Slabbert

Professor, Dr. Melville Saayman

Institution awarding the Ph. D. Degree: North West University (NWU), Potchefstroom Campus, South Africa

Date of defence: 20/11/2017

(c) 2018 Varna University of Management. All rights reserved

Citation: Woyo, E. (2018) An assessment of brand Zimbabwe's competitiveness and attractiveness as a tourism destination. Doctoral Dissertation Summary. European Journal of Tourism Research 20, pp. 149-152

\section{Goal and objectives of the dissertation Goal}

The primary goal of the study was to develop a competitiveness and attractiveness assessment framework for brand Zimbabwe as a tourism destination. In pursuance of this goal, the study formulated four key objectives as follows:

$\checkmark \quad$ To evaluate destination branding as a strategy for building competitive and attractive destination brands.

$\checkmark \quad$ To analyse and examine the aspects of competitiveness and attractiveness from a destination perspective.

To examine factors that influence the competitiveness and attractiveness of brand Zimbabwe as a tourism destination

$\checkmark$ To draw conclusions and make practical recommendations concerning the application of the study's proposed framework.

DOCTORAL DISSERTATION

\section{Methodology}

The study followed a quantitative research approach. Two surveys were done, using both the demand and supply perspectives. On one hand, the demand survey was conducted to assess the attractiveness of Zimbabwe as a tourist destination. On the other hand, the supply survey was conducted to assess the competitiveness of Zimbabwe as a tourism destination. The measuring constructs of both surveys were based on literature as well as new constructs that were self-generated by the researcher where possible. Branding constructs were added as new constructs in both surveys and were tested specifically for this study. Demand data were collected from 500 international tourists that visited Zimbabwe's popular tourist attractions such as Victoria Falls, Harare, Eastern Highlands and Great Zimbabwe. Supply data were collected from 320 tourism and hospitality 
establishments from the same destinations. Both surveys were done at the same time in all the four tourism destinations.

Descriptive statistics were used to describe both the demand and supply profiles. Exploratory factor analyses were used to identify competitiveness and attractiveness factors for brand Zimbabwe as a tourism destination. The relationship between attractiveness and competitiveness factors was established using Spearman's rank order correlations. Additional relationships between destination attractiveness and competitiveness with other variables were established using independent $t$-tests and ANOVA. Significant contributors for destination brand loyalty as well as prosperity of destination residents and investment were analysed by means of multiple stepwise regression analysis.

\section{Results}

From the demand results, 12 attractiveness factors were revealed while 14 destination competitiveness factors were identified. The demand results showed that the most important destination attractiveness factors for brand Zimbabwe include destination ambiance, destination attractions and tourism amenities. Zimbabwe's attractiveness as a tourism destination was found to be affected by the price and external access factors. The most important competitiveness factors of Zimbabwe were identified in this study as satisfaction recommendations, destination quality and cultural attractiveness. As with the demand results, the competitiveness of Zimbabwe is greatly affected by its pricing model. Significant predictors for brand loyalty in the empirical context of Zimbabwe were found to be destination environment, destination brand identity, destination brand image and destination ambience. The predictors of destination prosperity and investment competitiveness in the empirical context of Zimbabwe were found to be satisfaction recommendations, destination branding outputs, satisfying brand experiences, cultural attractiveness, brand strategy effectiveness, price, politics and policies. Results of this study confirmed that destination

attractiveness

and

competitiveness factors are multi-faceted. The competitiveness and attractiveness assessment framework was therefore modelled based on key results.

\section{Theoretical conclusions}

This study contributes towards destination management planning literature, which is generally lacking in the context of Zimbabwe. According to Mkono (2012:207), there is a remarkable lack of studies on tourism planning in Zimbabwe. The major contribution of the study is the competitiveness and attractiveness assessment framework that was developed. The framework is useful in destination planning and contributes towards tourism planning literature in Zimbabwe. Empirical studies that have attempted to examine the link between destination branding and competitiveness as well as attractiveness are limited (Miličević et al., 2017:209). Therefore, the contribution of this study is that it investigated the relationship and, therefore, narrowed this literature gap. The study also enabled the development of measuring constructs that can be adopted for future research on this topic in similar tourism destinations.

\section{Practical application of the dissertation}

The proposed framework that was developed in the study serves as a tool for destination planning, destination marketing as well as destination brand strategy formulation. Moreso, the framework serves as a means through which Zimbabwe as a tourism destination can measure the effects of destination branding in relation to destination competitiveness and attractiveness aspects. Zimbabwe, through this framework, will be able to provide satisfying brand tourism experiences that are being sought by its tourist markets (customers). The framework that was developed can also be used by other similar developing countries in terms of destination planning and destination marketing.

The framework provides insights on how Zimbabwe as a destination can use destination branding to develop competitive 
advantage based on strategic destination management and visitor management practices. Consequently, the proposed framework provides a destination competitiveness and attractiveness template from which Zimbabwe, as a tourism destination, is able to track destination performance over a period of time. This will be a crucial step for Zimbabwe to determine whether the destination brand is growing in attractiveness and competitiveness.

\section{Content of the dissertation}

\section{Abstract of Chapter 1}

This chapter provides an overview of how the research study is arranged. It consists of an introduction, background to the study and the study's research problem. It also provides an overview of the research method that was employed. The objectives of the study and the definitions of key study concepts are also discussed in this chapter.

\section{Abstract of Chapter 2}

Chapter two examines the literature on destination branding and how the research fits into the gaps. This chapter provides a theoretical basis of destination branding in terms of relevant definitions and contextualisation of the concept as it pertains to Zimbabwe as a tourism destination. Aspects contributing to destination branding are analysed. The significance of destination branding is discussed and contextualised. The objective of this chapter is to provide a clearly defined premise for assessing destination branding efforts in the context of brand Zimbabwe's competitiveness and attractiveness as a tourism destination.

\section{Abstract of Chapter 3}

This chapter discusses the definitions and existing theories relating to the measurement of destination competitiveness and attractiveness. This is done by means of focusing on the origins, applications, challenges, methodological aspects, and framework classifications of competitiveness and attractiveness. The chapter also provides a contextual analysis for assessing destination competitiveness and attractiveness for brand Zimbabwe as a destination by evaluating existing frameworks. The purpose of this chapter is to discuss destination competitiveness and attractiveness measurement and how it applies to this study.

\begin{abstract}
Chapter 4
Chapter 4 outlines the research methodologies and describes the study area and parameters. It is in this chapter where the research strategy is outlined. It covers the population, sampling techniques, instrument design, data collection process, research approaches and the overall methodology employed in this study. This chapter includes an elaborate discussion on the development of the survey instruments by referring to the aspects impacting destination competitiveness and attractiveness as identified in literature. In addition, the statistical analyses used in this study are explained in this chapter.
\end{abstract}

\section{Abstract of Chapter 5}

The fifth chapter presents the analysis of data collected from a demand side survey. The purpose of this chapter is to discuss, analyse and interpret the empirical results of the demand survey data. Firstly, an in-depth descriptive analysis of data is discussed in this chapter. Secondly, the factor analysis of factors contributing to brand Zimbabwe's attractiveness as a tourism destination are presented, discussed and interpreted. Thirdly, aspects influencing Zimbabwe's attractiveness are explained using independent $t$-tests and ANOVA. The relationship between destination attractiveness factors is explained by means of correlations. Lastly, multiple regression analyses are used in this chapter to develop models and explain the significant destination attractiveness contributors towards destination brand loyalty in the empirical context of Zimbabwe as a tourism destination.

\section{Abstract of Chapter 6}

The sixth chapter presents the analysis of data collected from the supply side survey. The purpose of this chapter is to discuss, analyse and interpret the empirical results of the supply survey data. The first section of the 
chapter presents an in-depth discussion of descriptive results. The in-depth analysis of descriptive results of supply is followed by the factor analysis of the items that contribute towards brand Zimbabwe's competitiveness as a tourism destination. Statistical techniques that explain the relationship among variables are explained in the third section of the chapter by means of ANOVA and correlations. The final section of this chapter discusses and interprets the results of regression modelling with regard to the significant destination competitiveness factors on prosperity of residents and investment competitiveness in the empirical context of Zimbabwe as a tourism destination.

\section{Abstract of Chapter 7}

The purpose of this chapter is to outline the key conclusions of the study. The theoretical, methodological and practical contributions of the study are presented in this chapter. The chapter also discusses the recommendations and suggestions that should direct the agenda of future research on destination competitiveness and attractiveness. Recommendations in this study are made to assist destination managers in Zimbabwe on how to maximise their branding and marketing efforts in a way that builds and sustains a competitive and attractive destination brand. Limitations of the study are also identified in this chapter.

\section{References:}

Miličević, K., Mihalič, T., \& Sever, I. (2017). An investigation of the relationship between destination branding and destination competitiveness. Journal of Travel \& Tourism Marketing, 34(2), 209221.

Mkono, M. (2012). Zimbabwe's tourism woes in the last decade: Hindsight lessons for African tourism planners and managers. Tourism Planning \& Development, 9(2), 205-210. 